\title{
PATRICIAN LANDSCAPES AND THE PICTURESQUE IN NOTTINGHAMSHIRE c.1750-c.1850*
}

\section{Richard A Gaunt}

University of Nottingham

\begin{abstract}
:
This article considers the Dukeries estates of north Nottinghamshire in the hey-day of aristocratic power and prestige, from the mid-Georgian to the mid-Victorian period. It poses a contrast between visitors' impressions of the area as one of constancy and continuity, a point of reassurance in an age of political and social upheaval, and the reality of internal changes from within. Closely crowded as these estates were, their aristocratic owners competed with one another to fashion the most economically viable and aesthetically pleasing symbol of status and power. The article pays close attention to the hold which picturesque principles exercised on individual owners and considers the role of plantation, animals and water in parkland management and improvement. Finally, the article considers the extent to which the estates were sites of contestation; owners attempted to keep unwanted plebeian incursions at bay, whilst carefully controlling access on set-piece occasions such as coming-of-age festivities.
\end{abstract}

Keywords: Patrician, Picturesque, Landscape, Improvement, Romanticism, Toryism 
In September 1832, W. E. Gladstone visited Nottinghamshire for the first time. After spending time in Newark, making preparations for contesting his first parliamentary election, he made his way through Sherwood Forest to Clumber Park, the family seat of his electoral patron, the $4^{\text {th }}$ Duke of Newcastle. Gladstone's surroundings were apt to make him wax lyrical:

The road to Clumber lay through Sherwood Forest, and the fine artless baronial park of Lord Manvers. In the Forest, every oak was a model of ancient grandeur: each one might have served Robin Hood for his Trysting Tree. I never saw so fine a collection - and it was impossible to check the influx of the ideas suggested by this thoroughly aristocratical domain. Those ancient oaks, which had themselves seen the lapse of many generations, and so were monuments at once of permanence and of change, yet stretched forth their proud branches, some bare and blackened to the blast, others still green and pregnant with the promise of future years. Feelingly did they suggest by their strong similitude, the image of that ancient aristocracy, than which the world never saw one more powerful or more pure... To this latter class I am persuaded belongs the nobleman, whom I was then on my road to visit. ${ }^{1}$

Visitors to Sherwood Forest have rhapsodised its unchanging nature for centuries but, for Gladstone, speaking in the aftermath of the Great Reform Act of 1832, the contrast between this tranquil setting and the tumultuous nature of surrounding events assumed more than usual significance. $^{2}$ All the essential ingredients of Gladstone's picture were suggestive of a romanticised, tory landscape over which the writ of the aristocracy ran large; a landscape in which the ancient social hierarchy aped the ancient woodland landscape for its grandeur and longevity. Hence the evocation of trees, of slow maturation across the generations, of the legend of Robin Hood, all suggested, to those who thought as Gladstone thought at the time, the fitting nature of situating a continuous tradition of English noblemen amongst a continuous terrain of forest woodland. ${ }^{3}$

Ever since Horace Walpole described Nottinghamshire as 'the Dukeries' - in a not altogether complimentary way - in the mid-eighteenth century, the county has been synonymous with the 
splendour of its aristocratic estates; pre-eminent amongst them, the four parkland estates created by enclosing the moors and waste of Sherwood (or Shire Wood) Forest. ${ }^{4}$ From its origins under crown control and monastic habitation in medieval times, subject to the rules and penalties of forest law, which preserved the rights of game, timber and vegetation to the crown and its agents, Sherwood Forest had witnessed, in succeeding generations, the dissolution of the monasteries, the gradual translation and sale of crown property into aristocratic hands and the erosion (or abandonment) of the claims of forest law. ${ }^{5}$ The weak rights enjoyed by resident commoners meant that, by the mid-eighteenth century, a number of emergent ducal estates were able to expand their boundaries through purchase, inter-marriage, exchange, grant and enclosure. By the mid-eighteenth century, the former monastic establishments of Rufford (Cistercian), Newstead (Augustinian), Welbeck (Premonstratensian) and Worksop (Augustinian), had each been transformed into distinct aristocratic seats, together with a number of other sites, including the former Augustinian priories of Felly and Thurgarton and the Cluniac establishment at Lenton Abbey. ${ }^{6}$

The cumulative effect of this process was to create a series of compact, abutting estates, vested in the continuing ownership of successive generations of inter-related aristocrats. The core of the Dukeries estates - their principal houses and parks - were to be found on the sandy soils associated with the remnants of Sherwood Forest. In 1756, Horace Walpole described the region as 'a very heptarchy of little kingdoms elbowing one another' whilst Sir George Savile commented to Lord Rockingham in 1769 that 'four dukes, two lords and three rabbit warrens' constituted about half of the county. However, three of the Dukeries estates straggled eastwards over the clay lands of north Nottinghamshire, including many unenclosed parishes. The Laxton 
estate, which had ownership from Thoresby (Earl Manvers) and Rufford (Lumley-Savile), is a conspicuous example. ${ }^{7}$

The historic families to which Walpole's description referred - the Dukes of Kingston of Thoresby Park, the Dukes of Newcastle of Clumber Park, the Dukes of Portland of Welbeck Abbey, and the Dukes of Norfolk of Worksop Manor - were subject to the usual vicissitudes of time, fortune and impecunious heirs, as well as temperamental gene pools, which affected the succession to those estates. However, the advantages of place, situation and continuous ownership ensured that these landscapes survived, to a greater or lesser extent, down to the twentieth century. Indeed, though none of them today constitutes a ducal seat, this area of Nottinghamshire is still popularly referred to as 'the Dukeries' in homage to its aristocratic heyday. ${ }^{8}$

Nevertheless, the impression that these sites were unchanging, in the way that Gladstone's evocation implied, is mistaken. This article will discuss the ways in which a seemingly continuous landscape was subject to significant amounts of change from within. This change was dictated by a variety of motivations, not least the desire of the owners of these estates to improve them in a manner which reflected their own status and ambitions. They were also keenly aware of the visual and aesthetic movements of their day, as they related to landscape gardening and parkland management - particularly the picturesque - and the need to make their estates economically viable resources, in spite of the poor, acidic Bunter sandstone outcrop upon which the forest rested. ${ }^{9}$

After surveying each of the ducal estates in turn and outlining some of the major changes in the structure and landscaping of them, the article will go on to argue that these landscapes not only 
offered laboratories for experimentation by patricians influenced by the new fashion for the picturesque, but sites of contestation in the face of encroachment by unwanted (usually plebeian) influences. ${ }^{10}$ The care, maintenance and money expended on these ducal domains acted as a symbolic reminder of the continuing power and endurance of the families and social class of which they were the most obvious public manifestation in a period when they achieved the high water-mark of their influence and prestige. ${ }^{11}$ Though many of the estates have, in the last halfcentury, been re-configured as publicly accessible parks, subject to the dictates of mass tourism, part of their continuing allure to visitors remains the fact that, much as with Gladstone in 1832, they continue to evoke an idea of the exclusive, secluded lifestyles of the social elite. ${ }^{12}$

\section{The Dukeries estates}

Three of the four sites comprising the Dukeries estates had strong individual claims to antiquity. Worksop had been the site of an Augustinian priory from the $12^{\text {th }}$ to the $16^{\text {th }}$ century and a park had been established there as early as 1161; by the mid-eighteenth century, the estate encompassed 2000 acres. The Dukes of Norfolk assumed ownership of Worksop in 1701, inheriting a late- $16^{\text {th }}$ century mansion which had been built for the $6^{\text {th }}$ Earl of Shrewsbury by Robert Smythson. Extensive schemes for re-landscaping the gardens - notably Lord Petre's plans for the $9^{\text {th }}$ Duke of Norfolk in the 1730s - demonstrated, perhaps before any of the other ducal estates in Nottinghamshire, a move away from the type of formal gardens popularised in England by the example of Louis XIV's Versailles, towards a species of picturesque naturalism, with serpentine walks, scattered trees and interesting vistas opened up to view. ${ }^{13}$ This would later hall-mark the picturesque movement, which was in high favour from the 1790s to the 1850s, and so named because its leading practitioners sought inspiration in the picture-like variety and irregularity of landscapes as opposed to the sweeping views and vistas championed by more 
formal practitioners such as Lancelot 'Capability' Brown. ${ }^{14}$ At Worksop, by the 1770 s, pleasure grounds had been developed to the east of the house, encompassing a lake, bridge, menagerie, Gothic bench, Tuscan temple, greenhouse, bowling green and hot house.

Nor was the ancestral heart of Worksop neglected. After a major fire in 1761, the Duke of Norfolk commissioned a new Palladian style mansion of quadrangular design, indicative of the growing importance of the family's Nottinghamshire estates. Over the course of the next six years, the architect James Paine completed one wing of the projected masterpiece - though it was, as Pevsner remarked, a house in itself. This consisted of 23 bays and was completed at a cost of $£ 32,000$. However, after the death of the Duke and his direct heir in 1767, work went into abeyance. ${ }^{15}$ This coincided with the long-term decline in the family's landholdings in Nottinghamshire to the point at which, by the 1870 s, they only possessed two acres in the county. ${ }^{16}$ The seminal moment came in 1838 , when the $4^{\text {th }}$ Duke of Newcastle assumed ownership of Worksop Manor, after purchasing the estate from the $12^{\text {th }}$ Duke of Norfolk, at a cost of $£ 375,000$. Newcastle proceeded to demolish the house, which still resided in a state of semi-realised splendour, ensuring that the best of its ornaments were transferred to Clumber. He also sold off the land for farms and converted the manor offices into a more modest residence. Newcastle then proceeded to have the walls of Paine's masterpiece blown up by gunpowder; though, initially, without success:

The weight of wall to be thrown over was computed at 400 ton weight, \& the quantity of powder used was $42 \mathrm{lbs}$ [Newcastle observed after attending the scene] all being ready the signal was given $\& 3$ men lighted the trains which ignited the fuses - in about [a] minute [and a] $1 / 2$ the first explosion took place then others in succession which had an extremely fine effect \& must have resembled the bombardment of a town - the whole of the bottom of the wall was burst through \& split to pieces but yet the wall stood - the experiment failed - it was really extraordinary how the superstructure of the wall could remain upright with scarcely anything except a few loose stones to rest upon. ${ }^{17}$ 
Such an interventionist act of landscape alteration, symbolising the absorption of one ducal estate by another, is enough to belie any notion that the area was an unchanging rural arcadia set in aspic. Today a West Lodge, dating from 1763, the mid- $19^{\text {th }}$ Century South Lodge and Castle Farm to the south east of the house are the principal standing remains. ${ }^{18}$

Like Worksop, Welbeck Abbey, its immediate neighbour to the north, had religious origins. A Premonstratensian house was established in the time of King Stephen (1153-54) but, after the dissolution of the monasteries in the $16^{\text {th }}$ century, the estate was sold. Sir Charles Cavendish bought it in 1607 . By the mid- $18^{\text {th }}$ Century, Welbeck covered some 2300 acres. Succeeding generations of Cavendishes (notably Charles and his son William) employed succeeding generations of Smythsons (notably Robert and his son John) in developing the site, in line with Cavendish's property at Bolsover, in Derbyshire, as a means of indulging their equestrian passions. A riding school and stables were completed during the 1620s. By the time that Daniel Defoe visited Welbeck, a century later, ownership of the estate had transferred by marriage through the Cavendish family, first to the Harleys, Earls of Oxford, and thence to the CavendishBentinck Dukes of Portland. ${ }^{19}$ However, as Defoe's remarks demonstrate, the equestrian imprint of the family's Cavendish forebears were still uppermost:

[Welbeck has been] beautified with large additions, fine apartments, and good gardens; but particularly the park, well stocked with large timber, and the finest kind, as well as the largest quantity of deer that are anywhere to be seen; for the late Duke's delight being chiefly on horseback and in the chase, it is not to be wondered if he rather made his parks fine than his gardens, and his stables than his mansion-house; yet the house is noble, large, and magnificent. ${ }^{20}$

Much as had happened at Worksop, the formal $17^{\text {th }}$ Century gardens were swept away during the mid-eighteenth century, with a kitchen garden established by Francis Richardson in the 1740s and major planting undertaken to the east of the house. Richardson's talents were also deployed 
at Worksop and Thoresby. However, it was the appointment of William Speechley as head gardener, and his development of the home farm and kitchen gardens during the three decades after 1760, which was the key to Welbeck's transformation. Speechley, who was a published authority on hothouses, viticulture and domestic rural economy, transformed the productive capacity of the Welbeck estate within a generation. ${ }^{21}$ The enclosure of Norton common and the parishes of Carburton and Worksop increased the extent of the estate at its boundaries, whilst the further integration of the park and estate through landscaping and woodland led the $3^{\text {rd }}$ Duke of Portland to call in Humphry Repton of Romford. In doing so, Portland acknowledged Repton's status as the pioneer of the term 'landscape gardening' to describe acts of patrician landscape improvement. $^{22}$

If Repton's Memoirs are to be believed, it was Portland, who twice served as Prime Minister, to whom he was 'more deeply indebted than to any in my list of professional patrons...in the importance his kindness and partiality gave to my professional career, and still more from the varied knowledge I acquired from his taste and experience'. ${ }^{23}$ The Duke had succeeded to the family's Nottinghamshire estates on the death of his mother in 1785 and, by the time of his death, 24 years later, proceeded to make the Portland estates the ninth largest in the country. ${ }^{24}$ Repton came to Welbeck for the first time in 1789. He produced three of his famous 'Red Books', outlining his plans for the estate, in 1789, 1793 and 1803. The first proposed a large scale removal of earth to create a sloping bank which would 'highlight the splendour of the mansion house' and the deepening and extending of the lake and plantations. The second focused on the addition of architectural features, including a cottage, lodge and gate houses, whilst the third, never to be realised, scheme, gave detailed projections for a new mansion, to be situated 'at a distance from the decayed oak trees' which were such a distinctive part of the Welbeck 
landscape. ${ }^{25}$ However, the Duke was no passively fashionable 'improver', keen to delegate the task to his hired servants. As Repton remarked, at their first interview, the Duke had 'explained to me his wishes...in a manner so clear and decided that all diffidence in my own skill was removed'. Indeed, the Duke later expressed severe displeasure with Repton, when the latter proposed continuing the water which ran alongside the house to the other side of the park by way of 'the expedient of an island, which with two small bridges would remove the difficulty [of navigation] at one half the cost'. Portland was disgusted at compromising his plans for the sake of economy; Repton said that the Duke 'detested' the word 'when [it] applied to his own concerns', much preferring additional expense to any compromise solution. Nevertheless, after some gentle diplomacy by the Duchess, Repton's scheme prevailed. ${ }^{26}$

Portland was a devotee of the picturesque ideas then beginning to assume pre-eminence in landscape garden design. Repton recalled that the Duke 'looked with a more inquisitive eye than many professional artists, and he would discover effects of light and shade and combinations of form and colouring in landscape as if he were selecting subjects for his pencil (tho' I believe he never made a sketch)'. Together, the couple would follow 'the tracks of deer or sheep into the most sequestered haunts of the forest', pausing only to remark on some 'fresh scene of beauty or interest' as redolent of the landscapes of Salvator Rosa (1615-73) and Philip Reinagle (17491833), two landscape artists then widely collected by connoisseurs of the picturesque style. Likewise, Portland:

would cautiously approach the spot where a group of men and children were resting or taking their noon day's meal, and pointing out some beautiful contrast in their attitude, or cheerful smile on their countenance, he would stop in fear of destroying the magic of the picture by our intrusion. $^{27}$ 
Repton was also commissioned to work at Thoresby, the estate of the Dukes of Kingston, located to the south-east of Welbeck. Thoresby had been enclosed out of Sherwood Forest in 1683 and consisted of 2000 acres by the late eighteenth-century. A two-storey house made from brick with stone dressings (attributed to William Talman) was commissioned sometime after $1685 .^{28}$ As at Worksop, a major fire swept away this initial phase of building (in 1745) and the fashionable Georgian architect John Carr of York completed a second residence, built from brick with a stone basement, during the years 1767-72. When the house, outbuildings and furnishings are included in the scheme, the total cost was $£ 34,000 .^{29}$

In 1788, Charles Pierrepont succeeded his uncle, the $2^{\text {nd }}$ and last Duke of Kingston, as owner of Thoresby; he was created $1^{\text {st }}$ Earl Manvers in his own right in 1806. Pierrepont's inheritance consisted of some 10,000 acres in the south of the county (valued at over $£ 8,000$ ) and nearly 12,000 acres in north Nottinghamshire (worth nearly £6,000). ${ }^{30}$ Repton was commissioned to alter the early- $18^{\text {th }}$ century cascade, as part of Pierrepont's drive to improve and extend the house and parkland. This enterprise cost him in the region of $£ 30,000$, over the course of fifteen years. Repton's work on the new cascade and river complex beyond the head of the lake cost some $£ 500$ and commenced in $1791 .^{31}$ It involved transplanting from Creswell Crags, twelve miles away:

The rocky bed of a mountain stream, and some large masses of stone together with the bushes that were growing on the fissures. These were artfully placed with a large flat slab (called Nature's Bridge) around which the water foamed and roared so loud it was impossible to hear anyone speak.

Pierrepont was delighted with the results: 'The Cascade is perfect, scarce a day [passes] that I do not cross the "Nature's Bridge" to see and hear the roaring flood. The very rocks appear to shake! ${ }^{32}$ 
Clumber, the fourth of the ducal estates of Nottinghamshire, was the last and latest of the parkland estates to be created, the only one not to have been previously occupied by a monastic establishment and the first to be denuded of its aristocratic connections during the $20^{\text {th }}$ century. The estate rose like a meteor with the fortunes of the Cavendish and Pelham-Holles Dukes of Newcastle-upon-Tyne, who owned it until the mid-eighteenth century, and descended just as inexorably through successive generations of ownership by the Pelham-Clinton Dukes of Newcastle-under-Lyne thereafter. Of the ducal parks, Clumber was the largest, at some 4000 acres, but the family's continuous residency was also the briefest - spanning only 160 years from 1768-1928. A hunting lodge had been transformed into a mansion house for the $2^{\text {nd }}$ Duke of Newcastle-under-Lyne in the 1760 s and improved thereafter, not least by the $4^{\text {th }}$ and $5^{\text {th }}$ Dukes, before a fire necessitated major re-modelling in 1879 . In much the same way as the $4^{\text {th }}$ Duke had, without much thought, demolished Paine's Worksop Manor in the 1840s, so Clumber house was dismantled by his successors on the eve of World War Two. ${ }^{33}$

Clumber's success story emerged from the fact that some 3000 acres of forest waste was enclosed between 1704 and 1709. This was given the royal seal of approval retrospectively in 1711. Clumber took in the adjacent areas of Carburton, Hardwick and Bothamsall, whilst a further 1000 acres, most of it at the edges of the estate, was enclosed over the course of the $18^{\text {th }}$ century. Plantations, a serpentine lake, cascade, multiple lodges, gatehouses and sculptured park grounds, transformed the area; as Curtis remarked in the mid-1840s, 'within the life of man, a dreary wilderness has been converted into a paradise, in the midst of which stands this palace of enchantment'. This was the estate which Gladstone visited in the autumn of $1832 .^{34}$

Clumber's early development bore the particular imprint of the $2^{\text {nd }}$ Duke of Newcastle, who inherited the title and some 10,000 acres, mostly in north Nottinghamshire, in 1760. Over the 
next three decades, Newcastle transformed the estate from a hunting park into the family's principal family seat in the country. ${ }^{35}$ Newcastle had been advised in his youth by his counsellor and tutor, Joseph Spence, who was a devotee of the planting of trees and gardens. Likewise, Newcastle realised his ambitions for the built landscape of Clumber by employing the family's retained architect Stephen Wright, who had worked extensively on the Newcastle estate at Oatlands in Surrey. The $2^{\text {nd }}$ Duke's principal interests, shared with his neighbours at Welbeck, was hunting and shooting - an image well reflected in Francis Wheatley's painting, 'The Return from the Shoot' (1788), with the new mansion house at Clumber featuring in the distance. ${ }^{36}$

Though not strictly part of the ducal estates, mention should also be made of Rufford Abbey, the site of a former Cistercian Abbey which was given by the crown to George Talbot, $4^{\text {th }}$ Earl of Shrewsbury, in exchange for his Irish estates in 1538. The estate, which contained about 20 outlying farms and granges, was adapted for residential use by 1560 and multiple schemes for the development of its gardens followed in 1680, 1695 and during the 1730s. A fire destroyed 21 rooms of the old Abbey in 1692 but the $12^{\text {th }}$ century under croft survives to this day. Rufford passed through the ownership of the Savile family, who were related to the Pierreponts of Thoresby and Earls of Scarbrough of Sandbeck Park in Yorkshire. Sir George Savile, who inherited the estate in 1700 and added an additional 50 acres to it two years later, opened up rides through the woods in a picturesque manner. His son, another George, purchased land in adjacent areas - Ollerton, Boughton, Kirton and Egmanton being purchased from the Markham family for $£ 22,000$ during the mid-1740s - and enclosed a large quantity of common land, which was used to cultivate new crops (notably hops). ${ }^{37}$

In 1758, John Platt of Rotherham was employed to landscape the park to the east and south of the house, including the provision of a lake with islands and a boat house on the west bank. The 
lake was dammed at the north end of the estate stream in order to power the estate's corn mill. Much later, during 1837-41, the architect Anthony Salvin undertook work on behalf of John Lumley-Savile, $8^{\text {th }}$ Earl of Scarbrough, costing $£ 13,000$, in order to restore the property in the Jacobean revival style. The $4^{\text {th }}$ Duke of Newcastle, visiting Rufford at an early stage of proceedings, was impressed:

He is making thorough alterations \& repairs there, \& not before they are wanted, for every piece of wood appears to be as rotten as tinder - a vast quantity has been taken out \& all which I saw lying about was like touchwood...the original building is still extant in good preservation, \& Lord Scarbrough means to clear all the partitions \& interferences away so as to show the whole in its pure \& original state...I was not before aware that a building of such antiquity \& curiosity existed so near to me.

Later, Salvin was responsible for the design and completion of the third and current Thoresby Hall, which he completed for the $3^{\text {rd }}$ Earl Manvers, at a cost of $£ 170,000$, between 1862 and $1873^{38}$

\section{Patricians and the Picturesque}

Aside from the observation that fire was a greater stimulus to changes in the built landscape of Nottinghamshire's ducal estates than any other single phenomenon, three major conclusions emerge from this survey. First, these estates were the pre-eminent demonstration of the power and prestige of the families which owned them. Land was the essential pre-requisite of political, social and economic privilege in England and the natural resources of estates (including timber, game, water and crops) as well as their aesthetic presentation, provided the economic and social capital upon which these families depended for their position. To some extent, the close-crowded nature of the dukeries estates made this more, rather than less, imperative as the drive behind 
developments. The $4^{\text {th }}$ Duke of Newcastle, for example, kept a close eye on his neighbours' property, ruminating in a typically trenchant manner upon the sorry state of Welbeck in 1824:

Nothing could look more deplorably than all did there, the wretched furniture, the equally wretched care that is taken of the house \& place, make the whole a miserable concern. It is indeed disgraceful to a man of the Duke of Portland's situation \& fortune to allow things to get into such a state. ${ }^{39}$

However, the most spectacular example of rivalry between the dukes resulted from Newcastle's purchase of Worksop Manor in 1838. 'The Duke of Portland has got wind (too late) of the purchase...\& I suppose has expressed his vexation \& disappointment', Newcastle observed at the time. It is clear that Newcastle was motivated by the ambition to secure Worksop for himself, in part, to deprive Portland of the possession. However, as a noted ultra-Protestant, the Duke must also have relished the irony of securing the Nottinghamshire seat of Norfolk, the leading Catholic peer of the realm. ${ }^{40}$

However colourful these insights into the character of individual owners are, ducal proprietors, including Newcastle, appreciated the value of good relations with one another, in order to secure mutually advantageous adjustments of boundaries and the exchange of land between them. Whatever the political and personal differences between them, Norfolk and Newcastle were quite satisfied to continue with their transaction. This leads to the second major conclusion, the impact of individual dukes upon their properties. Unsurprisingly, new activity or initiatives often coincided with the succession of a new duke to the title. This reminds us that individual family members wished to make their mark upon their patrimony at the same time as ensuring that their principal function as owner - to pass the estate on intact to the next generation - remained uppermost. $^{41}$ 
Finally, ducal owners had the means, the contacts, the cultural tastes and the determination to place themselves in leading positions as landscape improvers and innovators in their own right. The role of Speechley and Repton at Welbeck, Spence and Wright at Clumber, Richardson at Worksop, Salvin at Rufford and Thoresby, was a manifestation of the continuing hold which patronage exercised upon the arts and architecture, during this period. ${ }^{42}$

In terms of landscape improvement, this trend manifested itself most clearly in respect of the increasing amount of attention given over to aesthetic considerations in parkland design. Gone, or at least less prominent, were the sweeping vistas and formal, geometric garden designs beloved of the $17^{\text {th }}$ and early $18^{\text {th }}$ century, much inspired by continental examples of landscape gardening, and reaching their apogee in the work of 'Capability' Brown. In their place came a renewed appreciation of the irregular, informal, undressed landscapes associated with picturesque writers and landscape gardeners such as Uvedale Price and Richard Woods. ${ }^{43}$

Viewed in this way, the picturesque validated exactly the same sort of organic values pioneered by Edmund Burke and other writers in the political sphere in reaction against the excesses of the French Revolution. ${ }^{44}$ It is not, perhaps, surprising that Portland was prominent in government at exactly the same period as he was seeking to improve Welbeck to picturesque standards. Though Repton was attacked by Price as 'the servile follower' of 'Capability' Brown, he enjoyed harmonious relations with Portland at Welbeck. ${ }^{45}$ Likewise, one of Price's disciples, William Sawrey Gilpin, found in the $4^{\text {th }}$ Duke of Newcastle, a ready and willing advocate of the picturesque ideal, which influenced the duke's interventions at Clumber from their first introduction in the mid-1820s until the end of Newcastle's life. ${ }^{46}$ 
Though Repton and Brown had, upon occasion, recommended the removal of whole villages in order to accommodate their plans, no such acts of wholesale vandalism were resorted to in Nottinghamshire, during this period. By 1820, there were some 50 parks in Nottinghamshire, accounting for about 23,000 acres (or $4 \%$ of the land area of the county). ${ }^{47}$ The nearest that individual owners came to intervention of this nature was in the diversion or re-routing of highways to manage access into their parks and keep traffic away from the house. This was a tactic which twice affected Rufford in the century before 1750 whilst, at Clumber, the $2^{\text {nd }}$ and $4^{\text {th }}$ Dukes of Newcastle ensured that the park was 'traversed by several roads...in all of which are to be found scenes of Arcadian beauty' ${ }^{48}$

A number of developments in parkland design combined the picturesque with the practical by appealing to the pocket, as well as the eye, of aristocratic owners. Perhaps the most notable and well documented was that 'spirit of planting' which scholars have noted as characteristic of the great ducal estates of Nottinghamshire, during this period. ${ }^{49}$

Landscape designers had always placed great value upon the integration of trees, grass and water but picturesque writers placed particular stress upon the siting of trees in groves and clumps with isolated single specimens set apart to distinguish their exotic credentials. A major stimulus to the growth of interest in trees was John Evelyn's Silva, first published in 1670, which ran through four editions between 1776 and 1812. By this time, the need for extensively replanting the once famed trees of Sherwood had become a matter of general comment. As early as the 1720s, Defoe commented on the paucity of its woodland when he noted that:

'tis now, as it were, given up to waste; even the wood which formerly made it so famous for thieves, are wasted; and if there was such a man as Robin Hood, a famous out-law and deer-stealer, that so many years harboured here, he would hardly find shelter for one week, if he was now to have been there. ${ }^{50}$ 
In these circumstances, the proliferation in planting, and the motivations which inspired it, from the mid-eighteenth century onwards, assume special significance. In his agricultural survey of Nottinghamshire, in 1798, Robert Lowe estimated that some 7000 acres had been planted in the forest and borders over the preceding thirty years. Clumber Park and Hardwick wood, which was still scrubland in the $1760 \mathrm{~s}$, when the $2^{\text {nd }}$ Duke began to transform it, had seen nearly half its entire acreage (1848 acres) planted by 1794 . Similar proportions of woodland acreage may be discerned at Thoresby (981 out of 1700 acres), Worksop (470 out of 1145 acres), Welbeck (400 out of 750 acres) and Rufford (491 out of 700 acres). ${ }^{51}$

Planting was sound economic logic on the ducal estates. Arthur Young calculated that the threshold between land suitable for agricultural cultivation and that only suited to trees was 20 s an acre; in these circumstances, new planting provided not only aesthetic qualities in design but shielded estates from the prurient eyes of outsiders. After an appropriate period, the timber could be cropped for use in such vital estate activities as providing gates, fences and drainage, joists, beams, rafters and brooms. Poles for colliery pits, for growing hops (a particular speciality at Rufford, where ash trees provided the raw materials), for enclosure and, in the early-Victorian era, for railways, were other useful by-products of this systematic scheme of plantation. It also coincided with a boom in the price of oak, in real terms (with prices rising some $40 \%$ in the east of England), whilst the proliferation in the number of books published on the subject of timber and woodland catered to the new market for advice about the nurturing of trees. ${ }^{52}$

Planting trees also assumed three symbolic functions. First, trees summoned up all the patriotic associations which reference to 'old oaks' and 'venerable growth' in Gladstone's time demonstrated earlier. The association between tree planting and the royal navy ('hearts of oak'), the wearing of sprigs of oak annually on 29 May - in commemoration of the restoration of the 
monarchy in 1660 - as well as the practice of inviting visiting dignitaries to plant trees in avenues or plantations, frequently deployed at Clumber in the time of the $4^{\text {th }}$ Duke of Newcastle, gave tangible expression to the idea of bequeathing something organic to posterity. At Rufford Park, the Broad Walk was replanted with Dresden beeches in honour of George III's visit during 1786. This was part of an extensive re-plantation scheme, amounting to nearly 500 acres, undertaken by Richard Lumley-Savile, in the two decades after he succeeded to the estate in 1784. Half a century later, the $4^{\text {th }}$ Duke of Newcastle laid the foundations for Lime Tree Avenue, the most famous and the longest avenue of its type in Europe. ${ }^{53}$

An even more evident association between plantation and patriotism occurred at Thoresby. In 1794, there were 981 acres of plantations in the park and environs, with over 300 acres more projected for planting. Charles Pierrepont advertised his credentials in the sphere by winning a Gold Medal from the Society of Arts for his oak plantations in 1803. The more prominent of the planted areas or clumps he established were named after naval heroes of the Seven Years and French Revolutionary Wars, including Rodney, Keppel, Boscawen, Howe and St Vincent, the latter named after Admiral Jervis's victory off the south west coast of Portugal in 1797. Pierrepont had served with many of these men, during an active naval career of two decades' duration, which had only ended when he became heir to his uncle's estates. Further nautical resonance was provided by the organisation of the clumps around the seascape of Thoresby Lake. This had been appropriately augmented by fortifications and towers and a private navy, manned by retired sailors, regularly sailed upon it. A comparable sea-scape, complete with resident fleet, was to be found at the $5^{\text {th }}$ Lord Byron's seat at Newstead Abbey whilst Clumber's vast 87 acre lake had two sailing vessels, The Salamanca - named after the 1812 campaign in 
which the $4^{\text {th }}$ Duke of Newcastle's brother-in-law saw action - and The Lincoln, named after the Earldom bestowed on heirs to the title. ${ }^{54}$

A third form of memorialisation through planting was of a more personal kind. This was the geometric plantation known as Apleyhead, a 139 acre site established on former moorland by the $2^{\text {nd }}$ Duke of Newcastle at Clumber as a living memorial to his wife, who died at the age of 33 in 1760. The planting was designed in such a way as to have clear views radiating outwards to different parts of the estate. ${ }^{55}$ In this respect, it is also worth noting the continuing romantic associations of the ancient oaks of Welbeck; in particular, the Major, Seven Sisters, Parliament and Greendale Oaks, which assumed the status of sites of special scientific interest in an era before that system of classification had been created. The oaks were lionised by contemporaries, both in picture - for example, in the sketches of the Worksop-based artist, Emma Wilmot - and in print - most famously, by Major Hayman Rooke. ${ }^{56}$ The reflections of Christopher Thomson, the Edwinstowe artisan who published his autobiography in the 1840 s, were typical of the genre:

Tradition says, that whilst the first Edward, and his princely retinue, were merrily chasing the panting deer, through the entangled paths of Sherwood, that a messenger arrived in breathless haste, bearing intelligence to his majesty, that his new subjects in Wales were in open revolt. The king instantly summoned his knights around him, and held an urgent council under this tree.

Thus the Parliament oak was born.

Of the Greendale oak, Thomson wrote even more elegiacally:

We cannot gaze upon it without a feeling of wonder, how such a weather-withered pile could stand the uprooting blasts of centuries, and when, to all human foresight, his dissolution was near, that he should again take a new lease of life, send out a vigorous stem, and gem it with a coronal of shining green! The tree is now forty feet high and is fifty feet in girt at the base. A century and a half ago, a carriage-road was cut through his tough heart...ten feet six inches high at the entrance, and six feet three inches wide. ${ }^{57}$ 
In 1826, the former royal woodlands of Birkland and Bilhagh were sold to the $4^{\text {th }}$ Duke of Portland by the crown and the $5^{\text {th }}$ Duke mounted a spirited defence of the area, against the encroachment of various railway development schemes, during the 1850 s. $^{58}$

If trees received a new lease of life upon the ducal estates during the later-Georgian period, the proliferation of deer within Sherwood showed evidence of decline (or, at least, concentration). Though deer continued to be valued as gifts, for sport, and in terms of raising revenue, a number of estate owners failed to inherit the hunting traditions of their forebears. An exception was the $7^{\text {th }}$ Lord Scarbrough, who died whilst out hunting after being thrown from his horse in the avenue near to the lodge in Haughton Park. ${ }^{59}$ Many owners also realised the incompatibility of keeping large quantities of deer in the vicinity of the crops they were seeking to encourage on their estates. Welbeck and Wollaton are, to this day, the Nottinghamshire estates which have preserved their deer herds for the longest, whilst deer enclosures were developed at Thoresby, Rufford and Worksop to preserve their stocks whilst protecting the crops. Though a park had, by definition, once been a place for raising deer, Clumber was effectively re-defined after the $2^{\text {nd }}$ Duke of Newcastle began to transform it in 1760 . The deer were either culled or removed to neighbouring Haughton Park, as the Duke pursued his plans of practical agricultural improvement on the estate. Elsewhere in the county, the deer parks of Clipstone (bought by the Earl of Devonshire in 1603), Bestwood (bought by the Gwynne Dukes of St Albans in 1687) and Nottingham (bought by the Earl of Rutland in 1623) had already been transferred out of crown control. $^{60}$

Flocks of sheep assumed the importance which deer had once enjoyed at Clumber, providing an essential means of grazing and manuring land which had been historically under-cultivated. This was the sheep-corn system by which sheep grazed in the day and were penned at night in order to 
fertilise the land ready for corn production. By the time Lowe visited Clumber in the 1790s, about half its 4000 acres had been turned over to practical agricultural schemes, including rearing significant quantities of livestock (in the form of pigs, cattle, horses and oxen). Within a space of two generations, the park had been transformed 'under excellent management [as Curtis observed], and in a state of progressive improvement'. Comparable developments were proceeding apace at Welbeck, during the same period, under the direction of William Speechley and his successors. ${ }^{61}$

\section{Contestation}

The final section of the article considers the extent to which the ducal parks of Nottinghamshire were sites of contestation, not least given the major social and political transformations affecting England more widely during this period.

It is undoubtedly the case that individual landowners could live in an almost constant state of paranoia about the potential loss of their property at the hands of a revolutionary crowd. As the $4^{\text {th }}$ Duke of Newcastle observed in 1833 , 'I cannot but reflect that in a few years my property may be wrested from me \& all that I am doing here, either be destroyed, or be for the benefit of some fierce Republican, or low but rapacious scoundrel of a revolution' ${ }^{62}$

But Newcastle had good reason for concern; his hard-line ultra-Tory opposition to parliamentary reform saw his property, Nottingham Castle, burned down in October 1831 and threats of similar incendiarism were issued against Clumber. As the Duke returned to Nottinghamshire, having voted down the Reform Bill in the House of Lords, his house was garrisoned with troops and cannon and the valuables walled up for safety in the cellars. Newcastle was warned by his ranger that he might be shot at as he went through the woods in Clumber Park 'where several men had 
been seen for several days lurking about'. An outhouse on the estate, together with its resident cow, had already been set alight. Having returned safely to the house, Newcastle instituted a sentry system and various strangers were taken into custody, in succeeding days, on suspicion of plotting mischief. Conversely, the receipt of addresses from Newcastle's tenantry, 'expressing their abhorrence of the late atrocious acts' and determination 'to defend me \& my property', reinforced his belief in the underlying loyalty of his own tenants and, within a few days, the threat had receded. ${ }^{63}$

It would be easy to take Newcastle's melodramatic rendition of these events as indicative of wider social cleavages between landowners and tenants. ${ }^{64}$ However, in one respect, the picturesque ideal of improvement, beloved by Newcastle no less than other estate owners, was a prophylactic against the sort of social revolution which he feared. Picturesque theorists encouraged the exercise of 'a more benevolent form of estate management [through] cultivating friendly relations with tenants and labourers and by limiting the extent and ambition' of their owners' ambitions. The most obvious manifestation of this was in the provision of more comfortable cottages for estate workers and tenants, 'in any number of architectural styles', which became a symbol of 'patrician benevolence' and paternalism. ${ }^{65}$ Likewise, the active planning of estate villages within park boundaries suggests a desire to integrate all those involved in sustaining the estate. The accounts of Stephen Wright at Clumber include 'a large coloured drawing for a new village with a plantation...together with the Farm House and the several cottages', together with drawings for a 'cellar, dairy, brewhouse and other improvements at Hardwick', an area at the north-east of the park. ${ }^{66}$ However, in many cases, these initiatives were sited at the borders of parks, in order to provide a suitable distance from the owner. In 1843, the agricultural commentator Alexander Somerville, writing under the pen-name of 'The 
Whistler at the Plough', criticised 'ornamental cottages and lodges at park gates as destitute of comfort as the hovel on the farm: mere ornament being everything, the comfort of the indwellers nothing, ${ }^{67}$

The very act of enclosing and empaling a park meant the abolition of all forms of common and customary rights within its remit and these rights were irrecoverable. Nottinghamshire's elite ducal parks were created before the parliamentary enclosure movement, which affected some 6.8 million acres of land (20\% of the countryside) nationally between 1750 and 1830 , resulting in the loss of about two-thirds of all former open fields. ${ }^{68}$ However, the consolidation of the ducal estates led to the erosion of the distinctive style of breck farming, which had historically been pursued at the forest's borders. Breck farming involved the temporary enclosure of tracts of open forest sheep-walk for between three and nine years to keep out livestock; the fences were removed at the end of this period of intensive cultivation in order to let the exhausted soil revert to scrub, heath and grass. ${ }^{69}$

Elsewhere, a concern for local employment prospects could helpfully combine with the pursuit of agricultural improvement. Between 1819 and 1837, the $4^{\text {th }}$ Duke of Portland constructed what has been described as the first sewage farm in England on his 1500 acre Clipstone Park estate, as a means of providing employment for local workers and drainage and irrigation for his estates. Through a system of flood dykes, the river Maun, rich in deposits of untreated sewage from Mansfield, was diverted along $71 / 2$ miles in order to fertilise 300 acres of former wasteland between Mansfield and Ollerton. Portland kept pace with new techniques, extending the scheme to include Edwinstowe and the Poulter valley between Norton and Carburton and improving its technical capabilities. The total cost was in the region of $£ 37,000$ but it increased the yield at Clipstone tenfold. Curtis described the scheme in glowing terms: 
By this contrivance, one of the first, and perhaps most capricious elements of vegetable nutrition, is placed under human control; a deficiency of rain can at all times be amply supplied by sluices and floodgates, and by the gradual slope of the meadows, any occasional redundance is carried off by the natural channel of the Maun. The value of this project is very perceptible during its whole length; a perennial fertility is maintained, and luxuriant crops of grass and clover flourish over a district where comparative sterility once reigned in absolute and apparently interminable power. If it has not already, it will in time, amply repay the immense outlay incurred in its formation. ${ }^{70}$

Extensive water meadows were also a conspicuous feature of the Clumber and Thoresby estates.

At other times, ducal owners actively encouraged incursions to their parks; most notably, at significant moments in the lives of their family such as the coming-of-age or nuptials of the heir to the estate. A good illustration is the celebration of the Earl of Lincoln's marriage at Clumber in January 1833. The $4^{\text {th }}$ Duke of Newcastle sent a general invitation to his tenantry, inviting them to meet the newly-married couple on their return into the county; this was, as he put it, to 'make what they do voluntary on their parts'. Newcastle then arranged to accommodate up to 1200 people in a temporary dinner suite in the park and adorned the estate with decorations and triumphal arches. Two days of feasting and celebration followed; on the first, the couple were escorted to the park's boundary by the local residents of Worksop, at which point a procession of Newcastle's tenants received them and proceeded towards the house 'headed by flags \& Music'. After being called to dinner by the firing of guns - probably the same ones that had been installed to repel potential invaders only a year before - the festivities commenced. The following day, up to 3000 people, including the cottagers '\& poorer people', had feasts in relays of 600 at a time and were entertained by fireworks provided for the purpose. Throughout the day, Newcastle was gratified to observe the good order, regularity and decorum of his guests, 'men, women \& children' alike. Nevertheless, the event was not without its revelry for, as one attendee observed afterwards, 'Everybody seemed quite merry... There were a great lot of men who could not find 
their horses, and doubtless the forest would afford a good many amusing scenes during the night'. 71

\section{Conclusion}

The celebration of Lord Lincoln's marriage came four months after Gladstone's first visit to Nottinghamshire and his admiring comments on the constancy and romanticism of the forest landscape. It would be foolish to conclude that Clumber - or any of the other Dukeries estates were models of social harmony, untouched by the incursions of the outside world. For every collective celebratory gathering convened by a Duke of Newcastle there were a host of minor, simmering acts of discontent and resentment played out in the daily lives of estate workers, tenant farmers and agents. The mantraps and spring guns with which owners preserved their game, timber and vegetation could lead to violent confrontations. For example, in the 'Rufford Affray' of 1851, 40 poachers from Mansfield and Sutton-in-Ashfield became embroiled in a struggle with ten gamekeepers, one of whom, William Roberts, later died from his injuries. Landowners were active in the protection of their properties, either in blocking former rights of way and challenging ancient rights of perambulation (a process made simpler after 1773 when the approval of two county magistrates was needed for assent as opposed to expensive acts of parliament) or through imposing an iron curtain of locked gates, fortified towers and other impediments to access. ${ }^{72}$

However, this article has principally been concerned with the development of patrician landscapes in Nottinghamshire during the hey-day of aristocratic wealth and power. The Dukeries estates were manifestations of the social prestige and power of their owners and expressed the varied influences (political, economic and aesthetic) which underpinned their turn 
towards the picturesque. Certain aspects of the landscape features of these estates - notably ancient woodland - were seen as expressing the constancy and continuity of the families which possessed them. However, these views mask an appreciation of the degree of internal change to which these estates were subjected. Tightly packed as they were in north Nottinghamshire, their owners engaged in a species of competition with one another. They also sought to make them economically viable, through the practical exploitation of resources, not just aesthetically pleasing. Planting, for example, could serve multiple functions including economic advancement, patriotic symbolism and personal commemoration. ${ }^{73}$

Today, the ducal parks which so bewitched visitors like Gladstone have been largely given over to tourism and the consumer nexus. The attendant paraphenalia of guidebooks, cream teas, outdoor craft centres, garden centres and gift shops is an all too familiar sight - if one that appeals to a particular type of visitor experience. ${ }^{74}$ Though the dukedom has died out, Welbeck is once again being lived in by members of the Portland family after a long period in which it was leased to the British army; Clumber, by contrast, went into the care of the National Trust in 1946, forty-two years before the extinction of the ducal line. Similarly, whilst Thoresby Hall has been re-configured as a private hotel, open 'strictly for adults' in the words of its advertising campaign, what remains of Worksop is closed to public access. By contrast, Rufford Abbey is maintained by English Heritage and the park by Nottinghamshire County Council. Yet, at the same time as the public has been let in - sometimes within carefully circumscribed limits - the principal attractions of these estates have become the landscapes rather than the houses which once sat at their heart. Today, Clumber and Rufford are pre-eminently country parks in which the historic built structures of the estate provide interesting and curious by-ways to divert the visitor. Conversely, Welbeck and Thoresby remain only partially accessible to public gaze. This is 
perhaps the greatest contrast between the modern day and the era explored in this article. Throughout the late-Georgian and early-Victorian era, ducal landscapes were symbolic of the power, wealth and extent of the families in whose ownership they rested, but they essentially framed an estate, the focal point of which was the mansion house. Today, at least in the Dukeries of Nottinghamshire, this is no longer the case.

* This article is based upon the 2013 Hoskins lecture, delivered at the University of Leicester on 6 July 2013. I am grateful to the Friends of the Centre for English Local History for inviting me to give the lecture and to all those who offered comments upon it subsequently, especially Professor John Beckett and the anonymous reviewer for the journal.

${ }^{1}$ John Brooke and Mary Sorensen (eds,), Prime Ministers' Papers: W.E. Gladstone, II (London, 1972), 22-23.

${ }^{2}$ On the romantic connotations of Sherwood, see James Carter, A Visit to Sherwood Forest including the Abbeys of Newstead, Rufford, and Welbeck... With a Critical Essay on the Life and Times of Robin Hood (London, 1850); Joseph Rodgers, The Scenery of Sherwood Forest with an Account of Some Eminent People Once Resident There (London, 1908).

${ }^{3}$ For these ideas, see Nigel Everett, The Tory View of Landscape (Yale, 1994); Mark Girouard, The Return to Camelot. Chivalry and the English Gentleman (Yale, 1981).

${ }^{4}$ W.S. Lewis (ed.), The Correspondence of Horace Walpole, Vol.32 The Countess of Upper Ossory (Yale, 1965), 374-75.

5 David Crook, 'The struggle over forest boundaries in Nottinghamshire, 1218-1227', Transactions of the Thoroton Society of Nottinghamshire, 83 (1979), 35-45; Nottinghamshire Archives, DD 148, 'Study on the Enclosure and Clearing of Sherwood Forest in the Seventeenth and Eighteenth Centuries' (n.d.).

${ }^{6}$ Ben Cowell, Patrician Landscapes, Plebian [sic] Cultures. Parks and Society in two English Counties, c.1750-1850 (unpublished PhD thesis, University of Nottingham, 1998), p. 128; Alan Cameron, 'Some Social Consequences of the Dissolution of the Monasteries in Nottinghamshire', Transactions of the Thoroton Society of Nottinghamshire, 79 (1975), 50-59.

${ }^{7}$ Cowell, Landscapes, pp. 69, 120; J V Beckett, A History of Laxton: England's Last Open-Field Village (Oxford, 1989).

${ }^{8}$ On their later history, see Roger A. Redfern, Dukeries of Nottinghamshire: and adjacent districts of Derbyshire and South Yorkshire (Clapham, Yorkshire, 1974); Robert J. Waller, The 
Dukeries Transformed: The Social and Political Development of a Twentieth-Century Coalfield (Oxford, 1983).

9 On improvement, see Susanne Seymour, 'The Dukeries Estates: Improving Land and Landscape in the Later Eighteenth Century', Transactions of the Thoroton Society of Nottinghamshire, 97 (1993), 117-28; Stephen Daniels and Susanne Seymour, 'Landscape Design and the Idea of Improvement 1730-1900' in R. A. Dodgshon and R. A. Butlin (eds.), An Historical Geography of England and Wales, $2^{\text {nd }}$ ed. (London, 1990), pp. 487-520.

10 Though the terminology of patrician and plebeian is largely associated with the work of E. P. Thompson, it has been applied to Nottinghamshire in the work of Cowell, Landscapes, amongst others; also see Susanne Seymour, Eighteenth-Century Parkland "Improvement" on the Dukeries' Estates of north Nottinghamshire (unpublished $\mathrm{PhD}$ thesis, University of Nottingham, 1988) and Ben Cowell, 'The Politics of Park Management in Nottinghamshire, c.1750-1850', Transactions of the Thoroton Society of Nottinghamshire, 101 (1997), 133-43.

${ }^{11}$ See J. V. Beckett, The Aristocracy in England, 1660-1914 (Oxford, 1986).

${ }^{12}$ Simon Schama, Landscape and Memory (London, 1995).

13 Virginia Baddeley, 'The Early Eighteenth Century Gardens of Worksop Manor, Nottinghamshire', Transactions of the Thoroton Society of Nottinghamshire, 100 (1996), 123-36.

14 Jane Brown, The Omnipotent Magician: Lancelot 'Capability' Brown 1716-83 (2011); Rosemary Hill, ‘As God Intended', London Review of Books (5 January 2012), 18-20.

${ }^{15}$ N. Pevsner and E. Williamson, The Buildings of England. Nottinghamshire (New Haven and London, 1979), pp. 390-92; M. Binney, 'Worksop Manor, Nottinghamshire', Country Life, 153 (1973), 678-82, 750-53.

16 John Bateman, The Great Landowners of Great Britain and Ireland [4 ${ }^{\text {th }}$ edition 1883] (Leicester, 1971), p. 334.

${ }^{17}$ Newcastle Diary, 19 September 1843 in Richard A. Gaunt (ed.), Unhappy Reactionary. The Diaries of the Fourth Duke of Newcastle-under-Lyne, 1822-50 (Thoroton Society Record Series, Vol. 43, Nottingham, 2003), p. 244.

${ }^{18}$ For a unique visual record of the dismantling of Worksop Manor, see Richard A. Gaunt (ed.), Emma's Sketchbook. Scenes of Nottinghamshire Life in the 1840s (Nottingham, 2013), pp. 6567.

${ }^{19}$ Lucy Worsley, Cavalier: The Biography of a Seventeenth Century Household (London, 2007); David N. Durant, The Smythson Circle: The Story of Six Great English Houses (London, 2011); A. S. Turberville, A History of Welbeck Abbey and its Owners, 2 vols. (London, 1938-9).

20 Daniel Defoe, A Tour through the Whole Island of Great Britain, (1724-6), (ed.) Pat Rogers (Harmondsworth, 1971), p. 457. 
${ }^{21}$ See the correspondence between Speechley and the $3^{\text {rd }}$ Duke of Portland in the University of Nottingham, Manuscripts and Special Collections [afterwards UNMASC], Pw F 8428-8491, covering the period 1767-95.

22 Claudia L. Johnson, 'Behold the genius of the place', Times Literary Supplement (30 July 2010), 17.

${ }^{23}$ A. Gore and G. Carter (eds.), Humphry Repton's Memoirs (Norwich, 2005), p. 29.

${ }^{24}$ Seymour, Dukeries Estates, pp. 145-7. By the 1870s, the family owned some 43,000 acres in Nottinghamshire; this represented under one-quarter of its total national landownership, the larger part of which consisted of over 118,000 acres in Scotland: Bateman, Great Landowners, p. 365.

${ }^{25}$ Cowell, Landscape, p. 97.

${ }^{26}$ Gore and Carter, Memoirs, pp. 30, 33-34.

${ }^{27}$ ibid., p. 32.

${ }^{28}$ For insights into the elusive Talman, see Giles Worsley, 'William Talman: Some Stylistic Suggestions', The Georgian Group Journal (1992), pp. 6-18.

${ }^{29}$ J. H. Hodson, 'The Building and Alteration of the Second Thoresby House, 1767-1804' in J. H. Hodson, P. A. Kennedy and Violet W. Walker (eds.), A Nottinghamshire Miscellany (Thoroton Society Record Series, Vol. 21, Nottingham, 1962), pp. 16-20.

${ }^{30}$ Seymour, Dukeries Estates, pp. 182-4. A century later, the family owned 26,771 acres in Nottinghamshire, by the far the largest concentration of their English estates: Bateman, Great Landowners, p. 298.

31 Cowell, Landscape, p. 97; UNMASC, Ma 4P21, Humphry Repton, Thoresby Park in Nottinghamshire, a seat of Charles Pierrepont, Esq (1791).

${ }^{32}$ Gore and Carter, Memoirs, pp. 115-16.

33 The family had already sold the Worksop estate in 1890. For the later period of Clumber's history, see John Fletcher, Ornament of Sherwood Forest: From Ducal Estate to Public Park (Bakewell, 2005).

34 Sara Morrison, 'The creation of Clumber Park, 1709-14. The last royal park of Sherwood Forest', Transactions of the Thoroton Society of Nottinghamshire, 106 (2002), 103-18; J. Curtis, A Topographical History of Nottingham and Nottinghamshire, Parts 1-8 (London, 1843-1844), p. 65; J. M. Clifton, “An enchanted palace”. Clumber Park, the Newcastle family seat' (unpublished BArch dissertation, University of Nottingham, 1979). 
35 Seymour, Dukeries Estates, pp. 197-9. By the 1870s, the family owned 34,467 acres in Nottinghamshire (yielding $£ 73,098$ ), with a further 1,080 acres (yielding $£ 1,449$ ) in Derbyshire, Lincolnshire and the West Riding of Yorkshire: Bateman, Great Landowners, p. 331.

${ }^{36}$ For the 2nd Duke's interventions at Clumber, see Richard A. Gaunt, 'Crafting Clumber: The Dukes of Newcastle and the Nottinghamshire Landscape', Landscape History, 33 (2012), 88-91.

${ }^{37}$ Pete Smith, 'Rufford Abbey and its Gardens in the $17^{\text {th }}$ and $18^{\text {th }}$ Centuries', English Heritage Historical Review, 4 (2009), 122-53, provides a comprehensive and beautifully illustrated history.

38 Newcastle Diary, 20 February 1837 in Gaunt, Unhappy Reactionary, p. 23; A. Beattie, Thoresby Hall, the Nottinghamshire Seat of the Countess Manvers: An Illustrated Survey \& Guide, 3rd ed., revised by C. W. N. Stanley (Derby, 1964).

${ }^{39}$ Newcastle Diary, 13 September 1824 in Gaunt, Unhappy Reactionary, p. 9.

${ }^{40}$ Newcastle Diary, 25 March, 4 April 1838 in Gaunt, Unhappy Reactionary, p. 214.

${ }^{41}$ Beckett, Aristocracy, pp. 43-90.

${ }^{42}$ For its prominence in all walks of life in Nottinghamshire, during this period, see Richard A. Gaunt (ed.), 'It's not what you know'. Patronage in Eighteenth and Nineteenth Century Nottinghamshire (Southwell, 2012).

43 Charles Watkins and Ben Cowell, Uvedale Price (1747-1829): Decoding the Picturesque (Woodbridge, 2012); idem., (eds.), Letters of Uvedale Price (Walpole Society, Vol. 68, Leeds, 2006); Fiona Cowell, Richard Woods (1715-1793): Master of the Pleasure Garden (Woodbridge, 2010).

${ }^{44}$ Everett, Tory View, pp. 91-122; Cowell, Landscape, p. 61.

${ }^{45}$ Gore and Carter, Memoirs, p. 141.

${ }^{46}$ Gaunt, 'Crafting Clumber', pp. 91-99.

${ }^{47}$ Cowell, Landscape, pp. 258-61 provides a comprehensive list.

${ }^{48}$ Curtis, Nottinghamshire, p. 66.

${ }^{49}$ Susanne Seymour, 'Landed estates, the "spirit of planting" and woodland management in later Georgian Britain: a case study from the Dukeries, Nottinghamshire' in Watkins, Woods and Forests, pp. 115-34; idem., "The "Spirit of Planting": eighteenth century parkland "improvement" on the Duke of Newcastle's north Nottinghamshire estates', The East Midland Geographer, 12 (1989), 5-13.

${ }^{50}$ Defoe, Tour, p. 455. 
${ }^{51}$ Robert Lowe, General View of the Agriculture of the County of Nottingham, with observations on the means of its improvement. Drawn up for the consideration of the Board of Agriculture and internal improvement (London, 1798); also see The Fourteenth Report of the Commissioners appointed to enquire into the State and Condition of the Woods, Forests and Land Revenues of the Crown, and to sell or alienate Fee Farm and other Unimproveable [sic] Rents in House of Commons Journal, 48 (1793), 467-511.

52 This paragraph is based on Seymour's work, cited at n.49.

53 Stephen Daniels, 'The Political Iconography of Woodland in later Georgian England' in D. Cosgrove and S. Daniels (eds.), The Iconography of Landscape: Essays on the Symbolic Representation, Design and Use of Past Environments (Cambridge, 1988), 43-82; Newcastle Diary, 14 February 1833 in Gaunt, Unhappy Reactionary, p. 201; UNMASC, Ne 3A/32, account for purchasing lime plants from Fisher, Holmes and Company (nursery and seedsmen of 12 King Street, Sheffield), 15 May 1838.

54 Susanne Seymour and Rupert Calvocoressi, 'Landscape Parks and the Memorialisation of Empire: The Pierreponts' "Naval Seascape" in Thoresby Park, Nottinghamshire during the French Wars, 1793-1815', Rural History, 18 (2007), 95-118; P. T. Wheeler, 'The Grounds of Newstead Abbey', The East Midland Geographer, 12 (1989), 53-58; Alistair Roach, 'Miniature Ships in Designed Landscapes', The Mariner's Mirror, 98 (2012), 46-50; Rosalys Coope and Pete Smith, Newstead Abbey. A Nottinghamshire Country House: Its Owners and Architectural History 1540-1931 (Thoroton Society Record Series, Vol. 48, Nottingham, 2014), p. 78.

55 Seymour, 'Spirit of Planting', pp. 9-11.

${ }^{56}$ Gaunt, Emma's Sketchbook, pp. 55-56; Hayman Rooke, Descriptions and Sketches of some Remarkable Oaks, in the Park At Welbeck, in the County of Nottingham, a Seat of His Grace The Duke of Portland. To which are added, observations on the age and durability of that tree. With remarks on the annual growth of the acorn (London, 1790).

${ }^{57}$ Christopher Thomson, The Autobiography of an Artisan (London, 1847), pp. 406-07; also see Charles Watkins, "A solemn and gloomy umbrage": changing interpretations of the ancient oaks of Sherwood Forest' in Charles Watkins (ed.), European Woods and Forests. Studies in Cultural History (Oxford, 1998), pp. 93-113; Charles Watkins, Trees, Woods and Forests. A Social and Cultural History (2014), chapter 6; Steven J. Clifton, 'The status of Sherwood's ancient oaks,' Transactions of the Thoroton Society of Nottinghamshire, 104 (2000), 51-64.

${ }^{58}$ Cowell, Landscape, p. 117; Tim Warner, 'Early landscape preservation in the Dukeries: The $5^{\text {th }}$ Duke of Portland and the coming of the Railways', The East Midland Geographer, 12 (1989), 34-43; Steven J. Clifton, 'The veteran trees of Birklands and Bilhaugh [sic], Sherwood Forest, Nottinghamshire,' English Nature Research Report, No. 361 (2000).

59 He was not much missed: Newcastle Diary, 26 February 1835 in Gaunt, Unhappy Reactionary, p. 104. 
${ }^{60}$ For the earlier history of Bestwood, see S. Gillett, 'Bestwood: a Sherwood Forest Park in the Seventeenth Century', Transactions of the Thoroton Society of Nottinghamshire, 89 (1985), 5774; T. H. Cook, 'Bestwood Park: Hunting ground of Kings', Nottinghamshire Historian, 14 (1974), 2-5.

${ }^{61}$ Curtis, Nottinghamshire, p. 122. For a dissenting voice about developments at Welbeck, see Michael Hanson (ed.), Ducal Estate Management in Georgian Nottinghamshire and Derbyshire: The Diary of William Gould, 1783-1788 (Thoroton Society Record Series, Vol. 44, Nottingham, 2006).

${ }^{62}$ Newcastle Diary, 4 September 1833 in Gaunt, Unhappy Reactionary, p. 202.

${ }^{63}$ Newcastle Diary, 13-19 October 1831 in Gaunt, Unhappy Reactionary, pp. 84-86.

${ }^{64}$ Curtis described the Reform Riots as 'a standing reproach and monument of outrages resulting from some of the basest of human passions, revenge and personal antipathy, from a mere difference of political opinion': Nottinghamshire, p. xv.

${ }^{65}$ Cowell, Landscape, pp. 61, 210, 213; the political dimensions of the picturesque are explored in T. Williamson, Polite Landscapes: Gardens and Society in Eighteenth-Century England (Stroud, 1995) and S. Copley and P. Garside, (eds.), The Politics of the Picturesque (Cambridge, 1994).

${ }^{66}$ UNMASC, Ne A $273 / 34,279 / 2$.

${ }^{67}$ Alexander Somerville, The Whistler at the Plough (ed.) K.D.M. Snell (London, 1989), pp. xi, 172.

${ }^{68}$ Cowell, Landscape, p. 113.

69 See D. V. Fowkes, 'Nottinghamshire Parks in the Eighteenth and Nineteenth Centuries', Transactions of the Thoroton Society of Nottinghamshire, 71 (1967), 72-89; idem., 'The Breck System of Sherwood Forest', Transactions of the Thoroton Society of Nottinghamshire, 81 (1977), 55-61.

${ }^{70}$ Curtis, Nottinghamshire, p. 64; also see David J. Bradbury, Secrets of Sherwood (Mansfield, 1987).

71 Newcastle Diary, 6-12, 16 January 1833 in Gaunt, Unhappy Reactionary, pp. 198-200; Godfrey Tallents' diary, 11 January 1833 in Richard A. Gaunt (ed.), Politics, Law and Society in Nottinghamshire. The Diaries of Godfrey Tallents of Newark, 1829-1839 (Nottingham, 2010), p. 44.

72 On events at Rufford, see Nottinghamshire Archives, DD 416/3, newspaper account of the 'Rufford Affray'; DD/SR/211/210, Gamekeeper's account book of Frederick Brock.

73 In this respect, the Dukeries were typical of the English aristocracy as a whole; Beckett, Aristocracy, pp. 206-86. 
74 A process described widely in Peter Mandler, The Fall and Rise of the Stately Home (Yale, 1999) and locally in Matthew Kempson, The State and the Country House in Nottinghamshire, 1937-1967 (unpublished PhD thesis, University of Nottingham, 2006). 